\title{
Measurement of I-129 in environmental samples by ICP-CRI-QMS: possibilities and limitations
}

\author{
By K. Li, E. Vogel and U. Krähenbüh* \\ Department of Chemistry and Biochemistry, University of Bern, Freiestrasse 3, 3012 Bern, Switzerland
}

(Received June 19, 2008; accepted in revised form February 27, 2009)

\section{I-129 / Environment / ICP-CRI-QMS / Pre-concentration / I-129 in seaweed and lake water}

\begin{abstract}
Summary. ${ }^{129} \mathrm{I}$ is preconcentrated from environmental samples and its accessibility is addressed for inductively coupled plasma quadrupole mass spectrometer with collision/reaction interface (ICP-CRI-QMS). By applying oxygen as CRI gas through skimmer cone, the signal of the interfering ${ }^{129} \mathrm{Xe}$ from the impurity of plasma gas can be eliminated while the formation of ${ }^{127} \mathrm{I}^{1} \mathrm{H}^{1} \mathrm{H}^{+}$can be partially removed. The improved ICP-QMS can be employed for investigation of ${ }^{129} \mathrm{I}$ in environmental samples with a ${ }^{129} \mathrm{I} /{ }^{127} \mathrm{I}$ ratio down to $10^{-7}$. The detection capability was demonstrated by measuring ${ }^{129} \mathrm{I}$ in seaweed samples collected around the nuclear fuel reprocessing plant at La Hague. The abundant ${ }^{127} \mathrm{I}$ in the sample matrix causes a serious problem and degrades the detection capability of the instrument when the concentration of ${ }^{127} \mathrm{I}$ is larger than $10^{5} \mathrm{ng} / \mathrm{g}$. Even combined with a sufficient pre-concentration procedure, ICP-QMS is not considered as a suitable technique for the analysis of ${ }^{129} \mathrm{I}$ in uncontaminated environmental samples with ${ }^{129} \mathrm{I} /{ }^{127} \mathrm{I}$ ratio of less than $10^{-7}$.

Results are presented for seaweed samples collected around La Hague. In addition, time dependant I concentrations and ratios are given for colloids and water sampled from Lake Thun.
\end{abstract}

\section{Introduction}

In recent years, the long-lived radionuclide ${ }^{129} \mathrm{I}\left(T_{1 / 2}=\right.$ $\left.1.57 \times 10^{7} \mathrm{a}\right)$ in the environment has received considerable attention as a by-product from the nuclear industry. The concerns either in radiation protection [1-6] or in scientific research [4,7-10] highlight the necessity of a suitable technique for ${ }^{129} \mathrm{I}$ analysis. The big challenge in the investigation of ${ }^{129} \mathrm{I}$ in the environment comes from the low concentration of ${ }^{129} \mathrm{I}$ in the environmental samples and its long half-life, which make it difficult to be determined either by mass spectrometry or by a radioactivity decay measurement. Radiochemical neutron activation analysis (RNAA) has been used for measuring ${ }^{129} \mathrm{I}$ in the environmental samples for many years [11]. However, this method requires the accessibility to a nuclear reactor. Different methods were developed for eliminating the need of such a facility and also for im-

\footnotetext{
*Author for correspondence

(E-mail: urs.kraehenbuehl@iac.unibe.ch).
}

proving the detection capability in broader context [11-16]. Up to date, accelerator mass spectrometry (AMS) is the most sensitive technique, which is capable to measure ${ }^{129} \mathrm{I}$ as low as $10^{7}$ atoms in $1 \mathrm{mg}$ of samples [14]. The pre-nuclear samples and samples with ${ }^{129} \mathrm{I} /{ }^{127} \mathrm{I}$ ratios lower than $10^{-10}$, which can be found in the uncontaminated area, are best measured by AMS.

The inductively coupled plasma-mass spectrometry (ICPMS) becomes attractive in this field since a large number of such instruments are in use and offer lower costs comparing with RNAA and AMS. ICP-MS has been applied in some studies to measure ${ }^{129} \mathrm{I}$ in biological materials, soil or water samples [17-24]. The detection thresholds of ${ }^{129} \mathrm{I}$ in these studies were in the range of $10^{-1}$ to $10^{-4} \mathrm{ng} / \mathrm{g}$. It is well understood that the measurement of ${ }^{129} \mathrm{I}$ by ICP-MS suffers from the isobaric interference of ${ }^{129} \mathrm{Xe}^{+}$due to xenon impurity in the plasma gas (i.e. Ar), and the polyatomic interference of ${ }^{127} \mathrm{I}^{1} \mathrm{H}^{1} \mathrm{H}^{+}$due to the high abundant ${ }^{127} \mathrm{I}$ present in the samples. The virtual background at atomic mass unit (AMU) 129 due to ${ }^{129} \mathrm{Xe}$ impurity is normally accounted for few $\mathrm{ng} / \mathrm{g}$ of ${ }^{129} \mathrm{I}$, which are 10 to 100 times higher than the concentration of ${ }^{129} \mathrm{I}$ that can be expected from a real environmental sample. Thus the background subtraction reveals great problem of precision. There is about the same Xe impurity measured in Ar gas with different qualities from $99.996 \%$ to $99.999 \%$. Several tests for removing Xe out of Ar gas by preferential adsorption failed [25]. For a complete separation of ${ }^{129} \mathrm{Xe}^{+}$and ${ }^{129} \mathrm{I}^{+}$, a resolving power of 600000 is required for the mass analyzer. This is also a challenge for a double focusing magnetic sector-field based high resolution MS system since most commercial high resolution systems offer a resolving power as high as 10000 [26]. On the other hand, the interference of ${ }^{127} \mathrm{I}^{1} \mathrm{H}^{1} \mathrm{H}^{+}$is more like the inherited problem from the sample matrix and ionization process within the plasma source. Although there is no suggestion that ICP-MS can, or ever likely will rival the sensitivity achieved by RNAA or AMS, the speed and simplicity are the advantages of this method comparing with the other two techniques. A significant improvement could be expected by optimizing the methodology used for extraction of pure and sufficient iodine during samples preparation, or by development of the instrumentation.

In the context of risk mitigation strategy related to the radionuclides in the environment, numerous materials, including activated carbon, anion-exchange resin, natural or- 
ganic matter and silver impregnated material (e.g. activated carbon, zeolite, silica gel or alumina), etc., have been evaluated for removing radioactive iodine from the effluent or off-gas of the nuclear fuel reprocessing plant. Despite the problems related to the cost and the possible leaching of silver under acidic condition, silver impregnated materials show generally more efficient sequestration of iodine comparing with other materials [27-32]. Taking into account the efficiencies reported in the literature and the stability of AgI, which is the dominant product from the sequestration of iodine when excess amount of silver exist [29], silver impregnated materials may be a solution for the tasks in which preconcentration of iodine from large amount of natural water is critical for analysis of ${ }^{129} \mathrm{I}$. Iodine fixed as AgI can be released into solution through reaction Eq. (1) given the solubility difference between $\mathrm{AgI}\left(K_{\mathrm{sp}}=10^{-17}\right)$ and $\mathrm{Ag}_{2} \mathrm{~S}$ $\left(K_{\mathrm{sp}}=10^{-51}\right)$. In this way, a measurement can be performed after isolating iodine from the bulk ions, which can be done with traditional solvent extraction.

$$
2 \operatorname{AgI}(\mathrm{s})+\mathrm{S}^{2-}(\mathrm{aq}) \Leftrightarrow \mathrm{Ag}_{2} \mathrm{~S}(\mathrm{~s})+2 \mathrm{I}^{-}(\mathrm{aq})
$$

On the other hand, applying the gas phase ion-molecule interaction to alter the ion population prior to the quadrupole mass analyzer has shown the possibility to improve the performance of the ICP-QMS for measuring trace elements or isotopes in presence of abundant stable isotopes or isobaric/polyatomic interference $[23,33,34]$. Utilizing the collision/reaction cell (CRC) technique, Izmer et al. [23] presented examples of iodine isotope ratio measurement of the contaminated sediments with ${ }^{129} \mathrm{I} /{ }^{127} \mathrm{I}$ at $10^{-7}$ level using mixture of oxygen and helium as reaction gases in hexapole CRC of an ICP-QMS system. Collision/reaction interface (CRI) is another way to utilizing the gas phase ion-molecule interaction for the purpose of elimination of interference in ICP-QMS measurement. The ion-molecule collision/reaction occurs in CRI system within the interface and the collision/reaction gas is injected directly into the plasma through the tips of the interface cones. The CRI system is currently only employed in Varian MS-820 system [35]. The capability of this technique on improving the performance of the ICP-QMS for ${ }^{129} \mathrm{I}$ measurement hasn't been reported.

The study presented here focus on the development of a procedure to make the ${ }^{129} \mathrm{I}$ accessible by ICP-MS measurement after being preconcentrated from natural water on silver impregnated material. The instrumentation was optimized to eliminate the interfering ${ }^{129} \mathrm{Xe}^{+}$and ${ }^{127} \mathrm{I}^{1} \mathrm{H}^{1} \mathrm{H}^{+}$on ${ }^{129} \mathrm{I}$ measurement by applying CRI technique in ICP-QMS system. This technique allows measuring isotopic ratios in seaweed samples from around La Hague, where as water and colloids from Lake Thun were analyzed using AMS technique.

\section{Experiment}

\subsection{Chemicals}

All the chemicals used, unless specially indicated, are analytical grade, bought from Merck or Sigma-Aldrich. The distilled water used (MQ water) was obtained by passing through MILLIPORE Quantum IX Ultrapure Ion-EM ${ }^{\mathrm{TM}}$
Cartridge and $0.22 \mu \mathrm{m}$ filter. The ${ }^{127} \mathrm{I}$ standard solution was prepared by dissolving Woodward iodine (received from ETH, Zürich) in hot $0.1 \mathrm{M} \mathrm{NaOH}$ solution. The ${ }^{129} \mathrm{I}$ standard was received from Spiez Laboratory, with a concentration of $24.4 \mathrm{~Bq} / \mathrm{g}$ in alkaline solution. The concentration of ${ }^{127} \mathrm{I}$ in the standard was measured by ICP-QMS after dilution. The gases were bought from Carbagas with quality of $99.998 \%$ for oxygen, $99.996 \%$ for argon and helium, $99.995 \%$ for ethane and $99.5 \%$ for hydrogen.

\subsection{Instruments}

Varian 820-MS was used to test the capability of CRI on improving the performance of the ICP-QMS for ${ }^{129} \mathrm{I}$ measurement. This instrument was also used without CRI to measure iodine, silver, zinc, mercury and iron during the experiment of preconcentration. $\gamma$-spectrometer (EG\&G ORTEC Model CFC-SJ, HPGe Well Detector) was used to measure the activity of the spiked ${ }^{125} \mathrm{I}$ for testing the efficiency of the preconcentration. 0.5 MV AMS [36] was used to measure the ratio of ${ }^{129} \mathrm{I} /{ }^{127} \mathrm{I}$ in seaweed samples to compare with the results from ICP-CRI-QMS, as well as in lake water samples to check the limits of the application of ICP-CRI-QMS.

\subsection{Preconcentration of iodine from natural water for ICP-CRI-QMS measurement}

$250 \mathrm{~L}$ of tap water were collected in a plastic tank. After being spiked with ${ }^{125} \mathrm{I}$ and acidified with $\mathrm{HCl}$ to $\mathrm{pH}=$ 1 , the water was pumped through a column of $\mathrm{Zn}(\mathrm{Hg})_{1 \%}$ ( $\varnothing=48 \mathrm{~mm}, h=370 \mathrm{~mm}, M_{\mathrm{Zn}}=2.7 \mathrm{~kg}$ ) and a column of $\mathrm{Ag} / \mathrm{AgCl}$ coated glass beads $(\varnothing=48 \mathrm{~mm}, h=9 \mathrm{~mm}$, $M_{\mathrm{Ag}}=8.6 \mathrm{~g}$ ) sequentially at a flow rate of $\sim 14 \mathrm{~mL} / \mathrm{s}$. The effluent from the columns was collected for treatment (coprecipitation with $1000 \mu \mathrm{g} / \mathrm{g}$ Fe at $\mathrm{pH}=7-8$ ) before discharge. Five times $200 \mathrm{~mL} \mathrm{Na}_{2} \mathrm{~S}(0.1 \mathrm{M})$ solution was used to wash $\mathrm{I}^{-}$down from the glass beads with thorough mixing after adsorption. The total 1-liter of the washing solution was filtered ( $1 \mu \mathrm{m}, \mathrm{PTFE})$ to get rid of the suspended $\mathrm{Ag}_{2} \mathrm{~S}$ particles. After the filtration, $54 \mathrm{~mL}$ of $\mathrm{H}_{2} \mathrm{O}_{2}(30 \%)$ followed by $8.57 \mathrm{~mL}$ of $\mathrm{HNO}_{3}(65 \%)$ were added to form $\mathrm{I}_{2}$. The extraction procedure using $100 \mathrm{~mL}$ of toluene followed by $10 \mathrm{~mL}$ of ascorbic acid (5\%) was conducted twice to extract iodine into $20 \mathrm{~mL}$ ascorbic acid solution. After adding $2.3 \mathrm{~mL}$ of $\mathrm{H}_{2} \mathrm{O}_{2}(30 \%)$ followed by $0.14 \mathrm{~mL}$ of $\mathrm{HNO}_{3}$ (65\%), the extraction procedure using $2 \mathrm{~mL}$ of toluene followed by $1 \mathrm{~mL}$ of ascorbic acid (5\%) was conducted twice again to concentrate the iodine finally into $2 \mathrm{~mL}$ of ascorbic acid $(5 \%)$ solution.

\subsection{Elimination of ${ }^{129} \mathrm{Xe}^{+}$and ${ }^{127} \mathrm{I}^{1} \mathrm{H}^{1} \mathrm{H}^{+}$by CRI}

Different gases, including helium, hydrogen, oxygen and ethane, were tested. The injection of mixture of gases was realized through a T-valve. Helium and hydrogen were controlled respectively by the internal mass flow controller (MFC) in the Varian 820-MS. Oxygen or ethane, as alternative gas, was controlled by an external MFC (BROOKS 5850s $500 \mathrm{~mL} / \mathrm{min}, \mathrm{N}_{2}$ ) combined with a regulator (BROOKS 5878) or a rotameter $\left(150 \mathrm{~mL} / \mathrm{min}\right.$ air $15^{\circ} \mathrm{C}$, $760 \mathrm{~mm} \mathrm{Hg}$ ). Whenever introducing gas from the external line, $200 \mathrm{~mL} / \mathrm{min}$ of helium was always applied to the sam- 
pler cone through internal MFC for maintaining the CRI working situation in the system-controlling program. The iodine solutions $(10 \mathrm{ng} / \mathrm{g}$ of iodine as iodate in MQ water) were used during the tests regarding the efficiencies of different gases in removing interference of ${ }^{129} \mathrm{Xe}^{+}$on ${ }^{129} \mathrm{I}^{+}$. The ${ }^{127} \mathrm{I}$ standard solutions diluted in $1 \%$ ascorbic acid were used for the tests regarding elimination of the interference of ${ }^{127} \mathrm{I}^{1} \mathrm{H}^{1} \mathrm{H}^{+}$on ${ }^{129} \mathrm{I}^{+}$. The ${ }^{129} \mathrm{I}$ standard solutions diluted in $1 \%$ ascorbic acid with different amount of ${ }^{127}$ I addition were used for the final tests on the detection limit.

\subsection{Analysis of ${ }^{129} I$ in the seaweed samples}

The seaweed samples, which were collected at different distances from the nuclear fuel reprocessing plant at La Hague, were digested with $\mathrm{HNO}_{3} / \mathrm{H}_{2} \mathrm{O}_{2}$ after lyophilization and grinding. ${ }^{129} \mathrm{I}$ was extracted from the digestate into toluene and back extracted into $1 \%$ ascorbic acid solution for ICPCRI-QMS measurement. A small fraction of the digestate was used to prepare AgI for AMS measurement [25]. The results from two measurements were compared.

\subsection{Analysis of ${ }^{129} \mathrm{I}$ in the Lake Thun}

To address the possibility of applying ICP-CRI-QMS to the measurement of ${ }^{129} \mathrm{I}$ in the uncontaminated environmental samples, the distribution of ${ }^{129} \mathrm{I}$ in Lake Thun $\left(+46^{\circ} 40^{\prime} 30.27^{\prime \prime} \mathrm{N},+7^{\circ} 44^{\prime} 32.73^{\prime \prime} \mathrm{E}\right)$, which is in the middle of Europe and without direct influence from the two well noticed nuclear fuel reprocessing plants at Sellafield and La Hague, were investigated by AMS on a monthly time scale for 6 months. About $40 \mathrm{~L}$ of water samples form the lake were filtered through $0.45 \mu \mathrm{m}$ membrane filters to collect more than $10 \mathrm{mg}$ particulate matter and $2 \mathrm{~L}$ of aqueous samples, respectively. The particles with filter were digested by microwave oven in TMAH (tetramethylammonium hydroxide) matrix, and then prepared for AMS measurement. The $2 \mathrm{~L}$ of aqueous samples were processed according to the procedure described by Szidat et al. [37].

\section{Results and discussion}

\subsection{The feasibility of the preconcentration procedure}

The final recovery of iodine in this pilot-scale experiment was $31 \%$ with $10^{5}$-fold reduction of sample volume. The recovery agreed well with the estimated value, i.e. $31-40 \%$ according to the results from the lab tests for individual steps. This implies the whole procedure is reliable and practicable for handling large amount of water sample. The efficiency can be improved if a closed container with on-line $\mathrm{pH}$ adjustment is employed at the beginning of the setup instead of the open tank collector. During the whole experiment, the solution passed was equal to 400 bed volume (BV) of the reduction column, i.e. column of $\mathrm{Zn}(\mathrm{Hg})_{1 \%}$ and $1500 \mathrm{BV}$ of the adsorption column, i.e. column of $\mathrm{Ag} / \mathrm{AgCl}$ coated glass beads. The iodine content in the effluent was kept lower than the detection limit of $0.01 \mathrm{ng} / \mathrm{g}$, while the original concentration of iodine in the water sample was $1.01 \mathrm{ng} / \mathrm{g}$. Leaching of $\mathrm{Zn}(\leq 1000 \mu \mathrm{g} / \mathrm{g}), \mathrm{Hg}(\leq 0.6 \mathrm{ng} / \mathrm{g}$ after $30 \mathrm{~min})$ and $\mathrm{Ag}(\leq 1 \mu \mathrm{g} / \mathrm{g})$ were kept constant for long time operation $(5 \mathrm{~h})$, indicating the stable performance of the columns. After co-precipitation with iron ions, the concentrations of $\mathrm{Hg}(0.0002 \mu \mathrm{g} / \mathrm{g}), \mathrm{Zn}(0.009 \mu \mathrm{g} / \mathrm{g})$ and $\mathrm{Ag}$ $(0.0003 \mu \mathrm{g} / \mathrm{g})$ in the finally discarded liquid waste, all met the regulations for drinking water [38]. The concentration of iron $(0.02 \mu \mathrm{g} / \mathrm{g})$ itself also met the regulation after the precipitation of the added $1 \mathrm{~g} / \mathrm{L}$ of effluent.

\subsection{Performance of CRI in elimination of interfering ${ }^{129} \mathrm{Xe}^{+}$and $\mathrm{IHH}^{+}$}

Charge transfer effectively eliminates the interference of ${ }^{129} \mathrm{Xe}^{+}$in the measurement of ${ }^{129} \mathrm{I}^{+}$by ICP-QMS. From the tested collision/reaction gases, i.e. $\mathrm{H}_{2}, \mathrm{He}, \mathrm{C}_{2} \mathrm{H}_{6}$ and $\mathrm{O}_{2}$, the best results are obtained by ethane and oxygen. This is understood considering the respective ionization potentials; the charge transfer reaction $v s$. the noble gas is exothermic and fast for ethane and oxygen. The polyatomic interference $\mathrm{IHH}^{+}$is most effectively reduced using $\mathrm{He}$ or $\mathrm{O}_{2}$ in the collision reaction interface. Combining these two data sets the optimal flow rate of $\mathrm{O}_{2}$ for the CRI was established. With a flow of $22 \mathrm{~mL} / \mathrm{min}$ of $\mathrm{O}_{2}$ the signal of ${ }^{129} \mathrm{Xe}^{+}$was reduced to the level of electronic background where as the intensity of ${ }^{129} \mathrm{I}^{+}$reached about $1 \%$ of the original value. This result is valid as long as the saturation concentration of ${ }^{127} \mathrm{I}$ $\left(5 \times 10^{6} \mathrm{ng} / \mathrm{g}\right)$ is not exceeded. This limit must be observed when a pre-concentration is applied for the measurement of ${ }^{129} \mathrm{I}$ in natural samples by ICP-MS. Similar results are obtained using a Perkin Elmer ELAN 6100 system with a DRC II.

\subsection{Possibilities of ICP-CRI-QMS in application to the contaminated environmental samples}

The concentrations of ${ }^{129} \mathrm{I}$ in the seaweed samples measured by ICP-CRI-QMS are listed in Table 1, together with the results from AMS for comparison. The concentrations of ${ }^{129} \mathrm{I}$ in samples varied from $\sim 5 \mathrm{ng} / \mathrm{g}$ (dry) to less than $0.1 \mathrm{ng} / \mathrm{g}$ (dry), corresponding to $\sim 10 \mathrm{~Bq} / \mathrm{kg}$ (fresh) to less than $0.12 \mathrm{~Bq} / \mathrm{kg}$ (fresh) given the measured water content of $69-80 \%$ in fresh seaweed. The decrease in concentration of ${ }^{129} \mathrm{I}$ from sample 1 to sample 3 indicates the decreased influence of releasing ${ }^{129} \mathrm{I}$ from the nuclear fuel reprocessing plant as a function of the increased distance from La Hague (Fig. 1). The calculated ratios of ${ }^{129} \mathrm{I} /{ }^{127} \mathrm{I}$ for sample 1 and 2 based on the concentrations of ${ }^{129} \mathrm{I}$ measured by ICPCRI-QMS were in good agreement with the results from AMS measurement. The concentrations of ${ }^{127} \mathrm{I}$ were in the range of $5 \times 10^{4}-2 \times 10^{5} \mathrm{ng} / \mathrm{g}$ in the measuring solutions. Good correlation coefficient $\left(R^{2}>0.999\right)$ was obtained for the samples with 3-point regression of standard addition, except for sample $3\left(R^{2}>0.99\right)$, where the unspiked sample had almost the same intensity as $1 \%$ ascorbic acid blank solution. The background signal in $1 \%$ ascorbic acid solution is $\sim 20$ counts/s, which corresponds to a BEC of $0.08 \mathrm{ng} / \mathrm{g}$ of ${ }^{129} \mathrm{I}$ (Table 1). For the reliable quantification using standard addition method, a concentration of ${ }^{129} \mathrm{I}$ in the unspiked sample as high as double amount of the background is necessary. Thus, the value of $0.16 \mathrm{ng} / \mathrm{g}$ is chosen as the method quantification limit (two times BEC) using standard addition. Given the volume of the measuring 


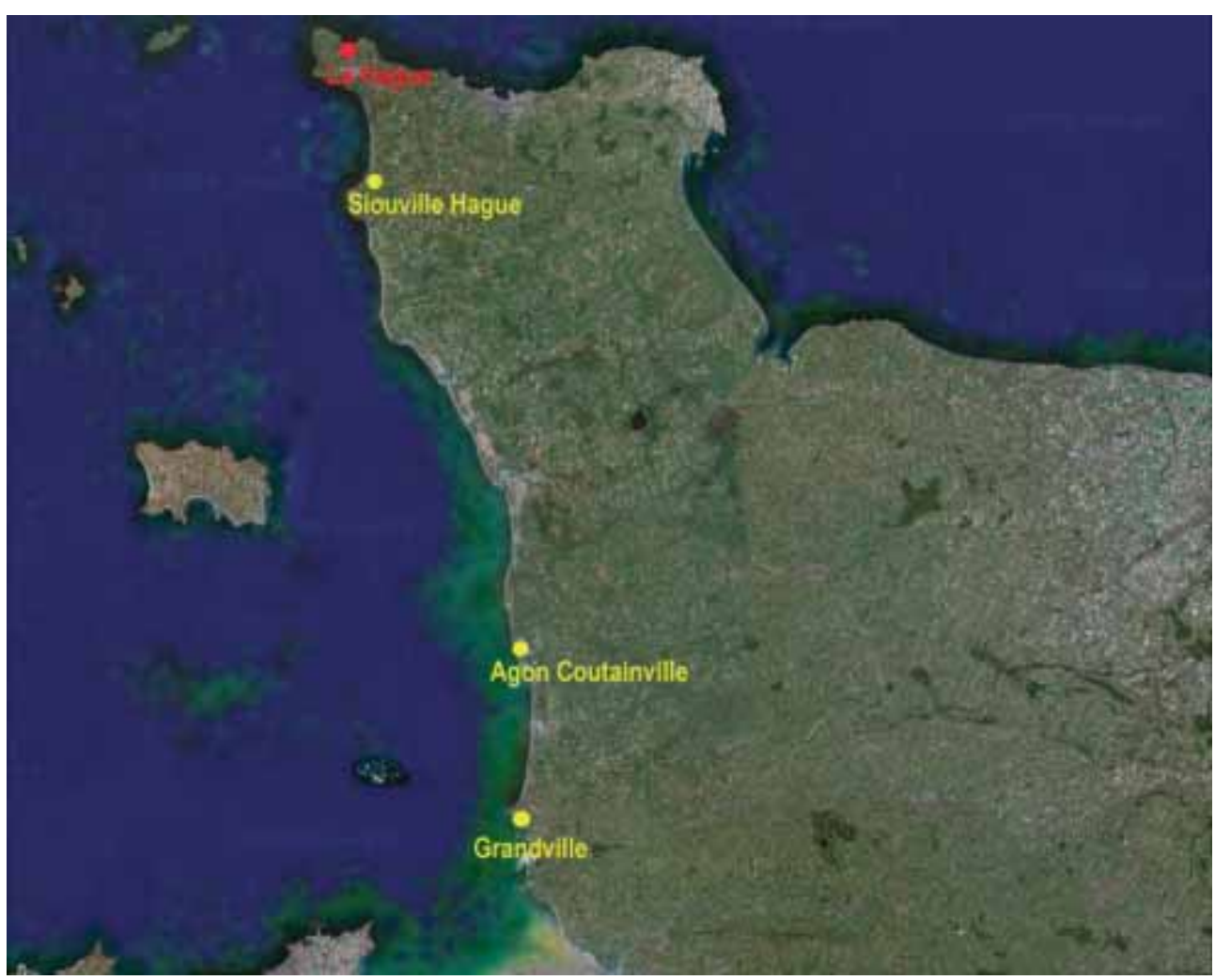

Fig. 1. Sampling sites for seaweed (google map).

Table 1. Concentrations of ${ }^{127} \mathrm{I}$ and ${ }^{129} \mathrm{I}$ in the seaweed samples measured by ICP-CRI-QMS.

\begin{tabular}{|c|c|c|c|c|c|c|}
\hline \multirow{3}{*}{ Sample } & \multirow{3}{*}{$\begin{array}{l}\text { Place of } \\
\text { Sampling }\end{array}$} & \multirow{3}{*}{$\begin{array}{c}\text { Distance } \\
\text { to La Hague }\end{array}$} & \multirow{3}{*}{$\begin{array}{c}{ }^{127} \mathrm{I} \\
\mu \mathrm{g} / \mathrm{g} \text { (dry) }\end{array}$} & \multicolumn{3}{|c|}{${ }^{129} \mathrm{I}$} \\
\hline & & & & ICP-C & RI-QMS & AMS \\
\hline & & & & ng/g (dry) & ${ }^{129} \mathrm{I} /{ }^{127} \mathrm{I} \times 10^{-7}$ & ${ }^{129} \mathrm{I} /{ }^{127} \mathrm{I} \times 10^{-7}$ \\
\hline 1 & Siouville Hague & $15 \mathrm{~km}$ & $908 \pm 33$ & $5.27 \pm 0.19$ & $58 \pm 4.4$ & $53 \pm 2.7$ \\
\hline 2 & Agon Coutainville & $75 \mathrm{~km}$ & $234 \pm 29$ & $0.23 \pm 0.02$ & $9.8 \pm 2.6$ & $9.0 \pm 0.5$ \\
\hline 3 & Granville & $95 \mathrm{~km}$ & $498 \pm 9$ & $<0.09$ & $<1.8$ & - \\
\hline
\end{tabular}

solution, i.e. $2 \mathrm{~mL}$, the yield of the total procedure, i.e. $35 \%$, the amount of sample used, i.e. $10 \mathrm{~g}$, the limit of $0.16 \mathrm{ng} / \mathrm{g}$ of ${ }^{129} \mathrm{I}$ in the measuring solution corresponds to $0.09 \mathrm{ng} / \mathrm{g}$ of ${ }^{129} \mathrm{I}$ in dry material, or approximate $18 \mathrm{ng} / \mathrm{kg}$ ${ }^{129} \mathrm{I}$ in fresh material (80\% water content).

\subsection{Measurement of samples from Lake Thun}

The water samples from Lake Thun (Fig. 2) measured by AMS shows the ratio of ${ }^{129} \mathrm{I} /{ }^{127} \mathrm{I}$ in the range of $10^{-8}$ either in aqueous phase or in solid phase. Suppose a preconcentration is conducted to get the reasonable amount of ${ }^{129} \mathrm{I}(0.1 \mathrm{ng} / \mathrm{g})$ for a ICP-QMS measurement, the associated amount of ${ }^{127} \mathrm{I}$ would be on the range of $10^{7} \mathrm{ng} / \mathrm{g}$. Due to the problem of $\mathrm{IHH}^{+}, \mathrm{ICP}-\mathrm{CRI}-\mathrm{QMS}$ is incapable of measuring ${ }^{129} \mathrm{I}$ in such samples. The obtained ratios of ${ }^{129} \mathrm{I} /{ }^{127} \mathrm{I}$ in Lake Thun are listed in Table 2. The concentrations of ${ }^{129} \mathrm{I}$ in the water of Lake Thun are in the range of $1.9 \times 10^{-14}-3.5 \times 10^{-14} \mathrm{~g} / \mathrm{L}$. These values are 20 to 40 times lower than that reported by Schnabel (2001) for the rain samples collected between 1994-1997 in Zürich, which had concentrations of ${ }^{129} \mathrm{I}$ in rang of $56 \times 10^{-14}-71 \times 10^{-14} \mathrm{~g} / \mathrm{L}$. Comparing with the more recent water samples collected between 1998 and 2004 from some European lakes around Switzer- land [39], which had the concentrations of ${ }^{129} \mathrm{I}$ in rang of $2.8 \times 10^{-14}-17 \times 10^{-14} \mathrm{~g} / \mathrm{L}$, the results obtained in this study are at the lower end of this range.

Although the difference of ${ }^{129} \mathrm{I} /{ }^{127} \mathrm{I}$ ratios between the surface water and the $100 \mathrm{~m}$ depth water was within the uncertainty range, there was a trend that higher concentration of ${ }^{129} \mathrm{I}$ occurred in the $100 \mathrm{~m}$ depth samples in Lake Thun, both in water and in particles. Considering the situation of stratification in the lake since the last overturn in Feb 2006, the higher ratio of ${ }^{129} \mathrm{I} /{ }^{127} \mathrm{I}$ in deep water can be explained as the former high depositions of ${ }^{129} \mathrm{I}$ into the lake and/or by re-suspension of older colloids from the ground. This is supported by the historical data of gaseous ${ }^{129} \mathrm{I}$ released from La Hague reprocessing plant from 1990 to 2007, which shows clearly a higher load of ${ }^{129} \mathrm{I}$ in the atmosphere before 2000 [39]. The gaseous releases from the reprocessing plant at Sellafield are higher than that from La Hague in recent years [40]. However a meteorological transport model studied by Schnabel et al. [41] showed the trajectories connecting Sellafield and Switzerland were the minor events satisfying the precipitation criteria, comparing with that of La Hague. The particles, which are mostly brought by the tributary rivers, are expected to be the sink of the ${ }^{129} \mathrm{I}$ within the water column. They exhibit an accumulation effect on io- 


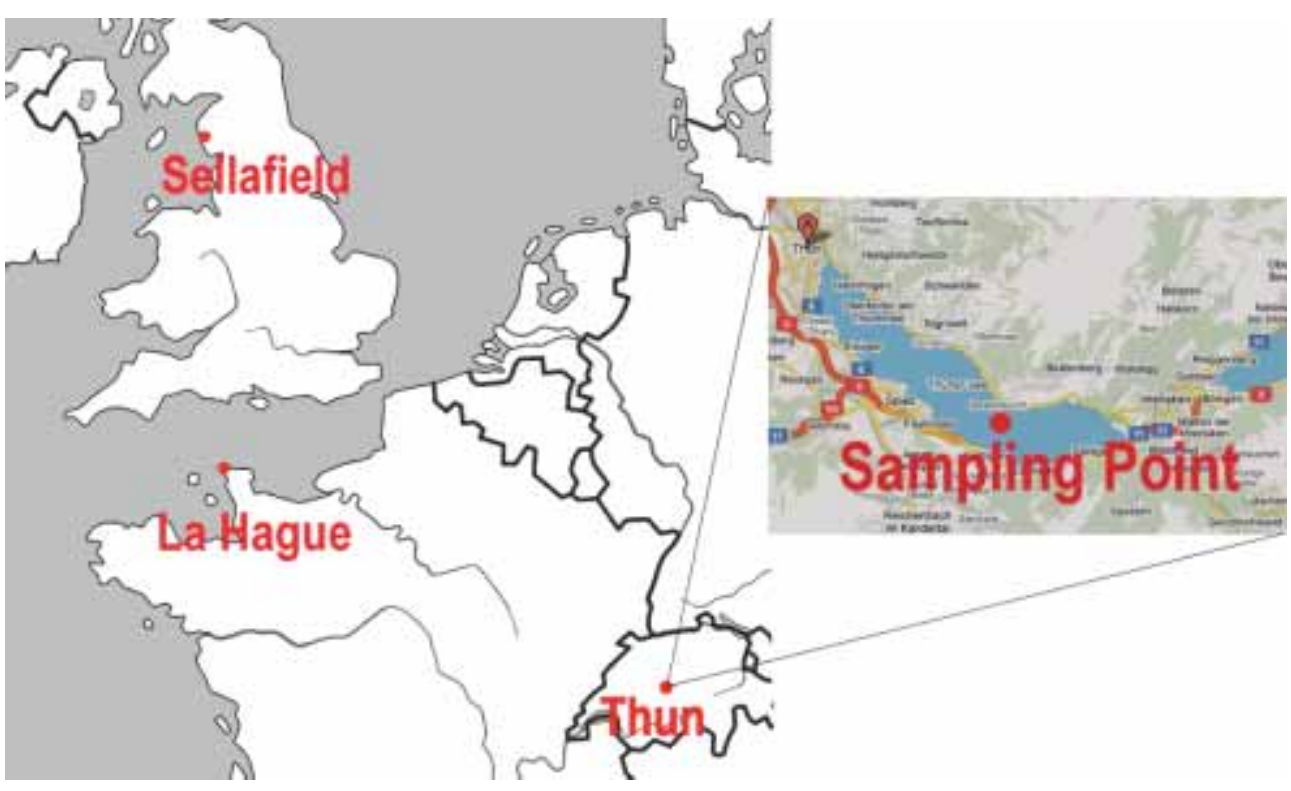

Fig. 2. Map of Lake Thun showing the sampling location and distance to emission sites (map Schweizer Weltatlas).

Table 2. Time dependant distribution of ${ }^{127} \mathrm{I}$ and ${ }^{129} \mathrm{I}$ in Lake Thun during 2007.

\begin{tabular}{lcccccccc}
\hline & Phase & Depth & Jun & Jul & Aug & Sep & Nov & Dec \\
\hline${ }^{127} \mathrm{I}$ & Particulate & $0 \mathrm{~m}$ & - & $7.58 \pm 2.27$ & $6.99 \pm 0.59$ & $8.26 \pm 0.82$ & $16.1 \pm 1.1$ & $12.3 \pm 0.8$ \\
& $\left(\times 10^{-6} \mathrm{~g} / \mathrm{g}\right)$ & $100 \mathrm{~m}$ & - & $48.4 \pm 8.8$ & $38.5 \pm 3.9$ & $11.1 \pm 0.6$ & $46.3 \pm 1.4$ & $72.9 \pm 5.0$ \\
& Aqueous & $0 \mathrm{~m}$ & $8.77 \pm 0.15$ & $3.79 \pm 0.84$ & $10.7 \pm 0.3$ & $7.39 \pm 0.22$ & $8.01 \pm 0.32$ & $9.59 \pm 0.15$ \\
& $\left(\times 10^{-7} \mathrm{~g} / \mathrm{L}\right)$ & $100 \mathrm{~m}$ & $11.0 \pm 0.26$ & $4.07 \pm 0.83$ & $13.3 \pm 0.21$ & $9.50 \pm 0.20$ & $9.71 \pm 0.34$ & $10.2 \pm 0.1$ \\
\hline${ }^{129} \mathrm{I}$ & Aqueous & $0 \mathrm{~m}$ & $2.50 \pm 0.25$ & $2.18 \pm 0.14$ & $2.09 \pm 0.13$ & $2.07 \pm 0.14$ & $1.98 \pm 0.13$ & $2.18 \pm 0.15$ \\
& $\left(\times 10^{-14} \mathrm{~g} / \mathrm{L}\right)$ & $100 \mathrm{~m}$ & $3.46 \pm 0.20$ & $2.85 \pm 0.17$ & $3.02 \pm 0.18$ & $3.00 \pm 0.20$ & $2.83 \pm 0.18$ & $2.96 \pm 0.19$ \\
\hline${ }^{129} \mathrm{I} /{ }^{127} \mathrm{I}$ & Particulate & $0 \mathrm{~m}$ & - & - & -1.15 & $<1.53$ & $<1.12$ & - \\
& $\left(\times 10^{-8}\right)$ & $100 \mathrm{~m}$ & - & - & $1.15 \pm 0.48$ & $1.53 \pm 0.74$ & $1.12 \pm 0.47$ & - \\
& Aqueous & $0 \mathrm{~m}$ & $2.81 \pm 0.21$ & $5.68 \pm 2.07$ & $1.92 \pm 0.17$ & $2.75 \pm 0.27$ & $2.43 \pm 0.27$ & $2.24 \pm 0.19$ \\
& $\left(\times 10^{-8}\right)$ & $100 \mathrm{~m}$ & $3.08 \pm 0.25$ & $6.89 \pm 2.28$ & $2.24 \pm 0.17$ & $3.10 \pm 0.27$ & $2.87 \pm 0.30$ & $2.85 \pm 0.23$ \\
\hline
\end{tabular}

Note: The uncertainties of the values were calculated based on the $1 \sigma$ measuring uncertainty from ICP-QMS and AMS, as well as the estimated uncertainty from weighing (type B) according to NIST (1994) [42].

dine. The lower ratio of ${ }^{129} \mathrm{I} /{ }^{127} \mathrm{I}$ in the particles comparing with that in the water can be explained by the high concentration of the inherent ${ }^{127} \mathrm{I}$ from their sediment origin, i.e. calcite sediment. Although numerous interactions take place between different compartments of the lake system towards the equilibrium distribution of ${ }^{129} \mathrm{I}$ and ${ }^{127} \mathrm{I}$, the disequilibrium is always prevailing due to the slow rate of the isotopic exchange between iodide and iodate, as well as the mechanisms involved in the interconversions of iodine species.

\section{Conclusions}

By adaptation of silver impregnated material, it is possible to collect ${ }^{129} \mathrm{I}$ from large amount of natural water through an on-line setup and make ${ }^{129} \mathrm{I}$ accessible for the measurement by ICP-MS. The concerns regarding the harmful release of silver, zinc and mercury in the effluent from the setup can be solved by co-precipitation with iron hydroxide.

By applying oxygen as CRI gas through skimmer cone, the interfering ${ }^{129} \mathrm{Xe}^{+}$can be eliminated, the formation of ${ }^{127} \mathrm{I}^{1} \mathrm{H}^{1} \mathrm{H}^{+}$can be partially remedied. The ICP-CRI-QMS is sufficient for investigation of ${ }^{129} \mathrm{I}$ in the environmental samples with a ${ }^{129} \mathrm{I} /{ }^{127} \mathrm{I}$ ratio down to $10^{-7}$ as illustrated by seaweed samples.

It is the abundant ${ }^{127} \mathrm{I}$ in the sample matrix, instead of $\mathrm{Xe}$ from Ar gas, which causes a more serious problem and degrades the detection capability of the instrument when the concentration of ${ }^{127} \mathrm{I}$ is larger than $1 \times 10^{5} \mathrm{ng} / \mathrm{g}$. Even combined with a sufficient preconcentration procedure, ICPQMS is not considered as a suitable technique for the analysis of ${ }^{129} \mathrm{I}$ in uncontaminated environmental samples, such as the lake water in middle Europe, with ${ }^{129} \mathrm{I} /{ }^{127} \mathrm{I}$ ratio lower than $10^{-7}$.

To further extend the measuring capability of ICP-MS one possible way is the combination of CRI technique with sector-field or time of flight mass analyzer taking advantage of the CRI in elimination of ${ }^{129} \mathrm{Xe}^{+}$and the other two types of mass analyzer in better separation of ${ }^{129} \mathrm{I}$ from ${ }^{127} \mathrm{I}^{1} \mathrm{H}^{1} \mathrm{H}$. However, the tolerance of the two types of mass analyzer needs to be tested in advance regarding the high population of ${ }^{127} \mathrm{I}^{1} \mathrm{H}^{1} \mathrm{H}^{+}$ions.

The measured concentrations of ${ }^{129} \mathrm{I}$ for surface water of Lake Thun give results in the range of $2-3 \times 10^{-14} \mathrm{~g} / \mathrm{L}$. The 
water samples collected in $100 \mathrm{~m}$ depth show values about $30 \%$ higher for this iodine isotope compared to water from the surface.

Acknowledgment. This study was financially supported by Spiez Laboratory. Marc Stauffer, Alfred Jakob, Thomas Sarbach and Markus Astner provided assistance on DRC test. Colette Duret, Nolwenn Perron and Lionel Gozard collected the seaweed samples. Markus Zeh, Daniel Scheidegger and the lake police in Faulensee provided assistance for sampling excursion on Lake Thun. Dr. Vasily Alfimov performed the AMS analysis. The authors thank Dr. Sönke Szidat for reading the manuscript.

\section{References}

1. Kocher, D. C.: A dynamic model of the global iodine cycle and estimation of dose to the world population from releases of iodine129 to the environment. Environ. Int. 5, 15 (1981).

2. Hou, X., Dahlgaard, H., Nielsen, S. P., Ding, W.: Iodine-129 in human thyroids and seaweed in China. Sci. Total Environ. 246, 285 (2000).

3. Hou, X., Malencheko, A. F., Kucera, J., Dahlgaard, H., Nielsen, S. P.: Iodine-129 in thyroid and urine in Ukraine and Denmark. Sci. Total Environ. 302, 63 (2003).

4. Santschi, P. H., Schwehr, K. A.: ${ }^{129} \mathrm{I} /{ }^{127} \mathrm{I}$ as a new environmental tracer or geochronometer for biogeochemical or hydrodynamic processes in the hydrosphere and geosphere: the central role of organo-iodine. Sci. Total Environ. 321, 257 (2004).

5. Eisenbud, M., Gesell, T.: Environmental Radioactivity. Academic Press, San Diego (1997), p. 556.

6. Ikeda, K., Kawakita, T., Ohkubo, Y.: High level radio-active wastes reduction through fast reactor. Prog. Nucl. Energy 37, 163 $\overline{(2000)}$.

7. Hou, X.: Application of ${ }^{129} \mathrm{I}$ as an environmental tracer. J. Radioanal. Nucl. Chem. 262, 67 (2004)

8. Fabryka-Martin, J.: Natural ${ }^{129} \mathrm{I}$ as a ground-water tracer. M.Sc. Thesis, University of Arizona (1984).

9. Schwehr, K. A., Santschi, P. H., Moran, J. E., Elore, D.: Nearconcsevative behavior of ${ }^{129} \mathrm{I}$ in the orange county aquifer system, California. Appl. Geochem. 20, 1461 (2005).

10. Zhao, P., Hu, Q., Rose, T. P., Nimz, G. J., Zavarin, M.: distribution of ${ }^{99} \mathrm{Tc}$ and ${ }^{129} \mathrm{I}$ in the vicinity of underground nuclear tests at the Nevada Test Site. UCRL-CONF-220859 (2006).

11. Studier, H. M., Postmus, C., Mech, J., Walters, R. R., Sloth, E. N.: The use of ${ }^{129} \mathrm{I}$ as an isotopic tracer and its determination along with normal ${ }^{127} \mathrm{I}$ by neutron activation - the isolation of iodine from a variety of materials. J. Inorg. Nucl. Chem. 24(7), 755-761 (1962).

12. Goles, R. W., Fukuda, R. C., Cole, M. C., Brauer, F. P.: Detection of iodine-129 by laser-induced fluorescence spectrometry. Anal. Chem. 53, 776-778 (1981)

13. Strebin, R. S., Brauer, F. P., Kaye, J. H., Rapids, M. S., Stoffel, J. J.: Neutron activation and mass spectrometric measurement of ${ }^{129}$ I. J. Radioanal. Nucl. Chem. Lett. 127, 59 (1988).

14. Elmore, D., Gove, H. E., Ferraro, R., Kilius, L. R., Lee, H. W., Chang, K. H., Beukens, R. P., Litherland, A. W., Russo, C. J., Purser, K. H., Murrell, M. T, Finkel, R. C.: Determination of ${ }^{129} \mathrm{I}$ using tandem accelerator mass spectrometry. Nature 286, 138140 (1980).

15. McHugh, J. A., Sheffield, J. C.: Mass analysis of subnanogram quantities of iodine. Anal. Chem. 37(9), 1099-1101 (1965).

16. Rook, H. L., Suddueth, J. E., Becker, D. A.: Determination of iodine-129 at natural levels using neutron activation and isotopic separation. Anal. Chem. 47, 1557-1562 (1975).

17. Beals, D. M., Hayes, D. W.: Technetium-99, iodine-129 and tritium in the waters of the Savannah River Site. Sci. Total Environ. 173(174), 101-115 (1995).

18. Bienvenu, Ph., Brochard, E., Excoffier, E., Piccione, M.: Determination of iodine-129 by ICP-QMS in environmental samples. Can. J. Anal. Sci. Spectrosc. 49(6), 423-428 (2004).
19. Brown, C. F., Geiszler, K. N., Vickerman, T. S.: Extraction and quantitative analysis of iodine in solid and solution matrixes. Anal. Chem. 77(21), 7062-7066 (2005).

20. Brown, C. F., Geiszler, K. N., Lindberg, M. J.: Analysis of ${ }^{129} \mathrm{I}$ in groundwater samples: direct and quantitative results below the drinking water standard. Appl. Geochem. 22, 648-655 (2007).

21. Cox, R. J., Pickford, C. J.: Determination of iodine-129 in vegetable samples by inductively coupled plasma mass spectrometry. J. Anal. At. Spectrom. 7, 635-640 (1992).

22. Kerl, W., Becker, J. S., Dietze, H. J.: Determination of iodine using a special sample introduction system coupled to a doublefocusing sector field inductively coupled plasma mass spectrometer. J. Anal. At. Spectrom. 11, 723-726 (1996).

23. Izmer, A. V., Boulyga, S. F., Becker, J. S.: Determination of ${ }^{129} \mathrm{I} /{ }^{127} \mathrm{I}$ isotope ratios in liquid solutions and environmental soil samples by ICP-MS with hexapole collision cell. J. Anal. At. Spectrom. 18, 1339-1345 (2003).

24. Izmer, A. V., Boulyga, S. F., Zoriy, M. V., Becker, J. S.: Improvement of the detection limit for determination of ${ }^{129} \mathrm{I}$ in sediments by quadrupole inductively coupled plasma mass spectrometer with collision cell. J. Anal. At. Spectrom. 19, 1278-1280 (2004).

25. Li, K.: On the investigation of I-129 in the environment by ICPQMS: possibilities and limitations. Ph.D. thesis, Universität Bern (2008).

26. Thomas, R.: A Beginner's Guide to ICP-MS-VII. Spectroscopy 16, 22-27 (2001).

27. Behrens, H.: New insights into the chemical behavior of radioiodine in aquatic environments. In: Environmental Migration of Long-Lived Radionuclides. International Atomic Energy Agency, Vienna (1982), pp. 27-40.

28. Ho, P. C., Kraus, K. A.: Adsorption on inorganic materials-VII Adsorption of iodide on $\mathrm{AgCl}$-filled carbon. J. Inorg. Nucl. Chem. 43(3), 583-587 (1981).

29. Hoskins, J. S., Karanfil, T.: Removal and sequestration of iodide using silver-impregnated activated carbon. Environ. Sci. Technol. $\overline{\text { 36(4) }}, \overline{78} \overline{4}-\overline{789}(2002)$.

30. Kepak, F.: Removal of gaseous fission products by adsorption. J. Radioanal. Nucl. Chem. 142(1), 215-230 (1990).

31. Sinha, P. K., Lal, K. B., Ahmed, J.: Removal of radioiodine from liquid effluents. Waste Manag. 17(1) 33-37 (1997).

32. Tang, J., Ye, M., Mao, Y., Lu, S., Tang, Z., Guo, Z., Removal of radioiodine from nuclear-fuel-reprocessing off-gases with silvernitrate-impregnated silica gel. J. Radioanal. Nucl. Chem. 119(2), 109-118 (1987).

33. Boulyga, S. F., Becker, J. S.: Improvement of abundance sensitivity in a quadrupole-base ICP-MS instrument with a hexapole collision cell. J. Anal. At. Spectrom. 17, 1202-1206 (2002).

34. Eiden, G. C., Barinaga, C. J., Koppennaal, D. W.: Beneficial ion/ molecule reactions in elemental mass spectrometry. Rapid Commun. Mass Spectrom. 11, 37-42 (1997).

35. Wang, X. D., Kalinitchenko, I.: Principles and performance of Varian 820MS. ICP-MS Advantage Note, Varian Inc. (2005).

36. Stocker, M., Döbeli, M., Grajcar, M., Suter, M., Synal, H. A., Wacker, L.: A universal and competitive compact AMS facility. Nucl. Instrum. Methods Phys. Res. B 240, $483-489$ (2005).

37. Szidat, S., Schmidt, A., Handl, J., Jakob, D., Botsch, W., Michel, R., Synal, H. A., Schnabel, C., Suter, M., Lopez-Gutierrez, J. M., Städe, W.: Iodine-129: Sample preparation, quality control and analyses of pre-nuclear materials and of natural waters from Lower Saxony, Germany. Nucl. Instrum. Methods Phys. Res. B 172, 699-710 (2000).

38. U.S. EPA: Drinking water regulations. http://www.epa.gov/ OGWDW/regs.html (last access: April 2008).

39. http://www.cogema.fr.

40. Reithmeier, H., Lazarev, V., Rühm, W., Nolte, E.: ${ }^{129}$ I measurements in lake water for an estimate of regional ${ }^{129} \mathrm{I}$ depositions. Sci. Total Environ. 376, 285-293 (2007).

41. Schnabel, C., Lopez-Gutierrez, J. M., Szidat, S., Sprenger, M., Wernli, H., Beer, J., Synal, H. A.: On the origine of ${ }^{129} \mathrm{I}$ in rain water near Zürich. Radiochim. Acta 89, 818-822 (2001).

42. NIST Guidelines for evaluating and expressing the uncertainty of NIST measurements results. NIST Technical Note 1297 (1994). 